\title{
PENGELOLAAN HUTAN MANGROVE BERBASIS MASYARAKAT DI DESA KAMPUNG AMBONG KECAMATAN LIKUPANG TIMUR KABUPATEN MINAHASA UTARA
}

\author{
Natalia Kiolol \\ Wenny Tilaar \\ Wiske Rotinsulu
}

\begin{abstract}
This study aims to analyze the socio-economic factors that affect the management of mangrove forests, as well as describe the management of community-based mangrove forests in Kampung Ambong Village, Likupang Timur District, North Minahasa District. This research was conducted for 3 (three) months from August to October 2017. The research used analytical descriptive approach using survey method. Sampling used purposive sampling method. Furthermore, participation analysis used Likert Scale. The survey was conducted to 55 respondents in Desa Kampung Ambong, Likupang Timur Sub-district, North Minahasa District. The results showed that based on the Rank Spearman correlation, socio-economic factors ie education level and membership in organization had enough influenced community participation in mangrove forest management. The participation rate of Kampung Ambong Village community in community-based mangrove forest management is categorized as $47.27 \%$. Mangrove forest management have conducted by community members at Kampong Ambong Village, Likupang Timur Sub-district, North Minahasa District, in the form of rehabilitation which mostly plant Rhyzopora seedlings, as well as mangrove and supervision. This activity was carried out by the Tanjung Asa Forest Farmers Group.
\end{abstract}

Keywords: mangrove, participation, community-based mangrove management, North Minahasa District

\section{ABSTRAK}

Penelitian ini bertujuan untuk (1) menganalisis faktor-faktor sosial ekonomi yang mempengaruhi pengelolaan hutan mangrove, serta (2) mendeskripsikan pengelolaan hutan mangrove berbasis masyarakat di Desa Kampung Ambong, Kecamatan Likupang Timur, Kabupaten Minahasa Utara. Penelitian ini dilakukan selama 3 (tiga) bulan terhitung dari bulan Agustus - Oktober 2017. Pendekatan yang digunakan dalam penelitian ini adalah pendekatan deskriptif analitik dengan menggunakan survei. Pengambilan sampel menggunakan metode purposive sampling. Selanjutnya analisis partisipasi menggunakan Skala Likert. Survei dilakukan kepada 55 responden di Desa Kampung Ambong Kecamatan Likupang Timur Kabupaten Minahasa Utara. Hasil penelitian menunjukkan korelasi Rank Spearman, factor - faktor sosial ekonomi yaitu tingkat pendidikan dan keanggotaan dalam organisasi cukup mempengaruhi partisipasi masyarakat dalam pengelolaan hutan mangrove. Tingkat partisipasi masyarakat Desa Kampung Ambong dalam pengelolaan hutan mangrove berbasis masyarakat termasuk dalam kategori sedang 47,27\%. Pengelolaan hutan mangrove yang dilakukan masyarakat Desa Kampung Ambong Kecamatan Likupang Timur Kabupaten Minahasa Utara dalam bentuk rehabilitasi yang sebagian besar menanam bibit Rhyzopora, serta melakukan perawatan mangrove dan pengawasan. Kegiatan ini dilaksanakan oleh oleh Kelompok Tani Hutan Tanjung Asa.

Kata kunci : mangrove, partisipasi, pengelolaan mangrove berbasis masyarakat, Kabupaten Minahasa Utara 


\section{PENDAHULUAN}

\section{Latar Belakang}

Penduduk Indonesia sebagian besar bermukim di daerah pesisir pantai. Salah satu bentuk ekosistem alami yang khas dan unik adalah hutan mangrove yang terdapat di wilayah pesisir pantai, yang dipengaruhi oleh pasang surut air laut. Sumberdaya pesisir berperan penting dalam mendukung pembangunan ekonomi daerah maupun nasional. Kegiatan pembangunan di wilayah pesisir semakin berkembang diberbagai sektor antara lain pemukiman, pariwisata, perikanan dan sebagainya. Perkembangan ini selalu di ikuti dengan tingginya kepadatan penduduk, yang menimbulkan permasalahan lingkungan di beberapa wilayah pesisir di Indonesia seperti terjadinya degradasi ekosistem alami yaitu hutan mangrove akibat pembangunan yang tidak berwawasan lingkungan.

Hutan mangrove merupakan salah satu ekosistem pesisir yang mengalami tingkat degradasi yang tinggi akibat pola pemanfaatannya yang tidak memperhatikan aspek kelestariannya. Kawasan mangrove mempunyai peranan penting bagi manuasia maupun hewan yang tinggal di dalam maupun di sekitarnya. Habitat hutan mangrove mempunyai karakteristik tersendiri, umumnya tumbuh pada daerah intertidal dimana jenis tanahnya berlumpur, berlempung dan berpasir. Selain itu, daerahnya tergenang air laut secara berkala, menerima pasokan air tawar yang cukup, terlindung dari gelombang besar dan arus pasang surut yang kuat dan mempunyai salinitas air 2-38 \%o (Bengen, 2000). Hutan mangrove merupakan kawasan lahan basah dengan karakteristik yang unik dan merupakan sumberdaya alam yang berperan ganda baik ditinjau dari aspek ekonomi maupun ekologi. Secara fisik, hutan mangrove dapat berfungsi untuk menjaga garis pantai agar stabil, mempercepat perluasan lahan, melindungi pantai dan tebing sungai serta mengolah bahan limbah. Fungsi biologis hutan mangrove sebagai tempat pembenihan ikan, udang, kerang dan jenis biota lainnya, tempat bersarangnya burung dan habitat alami dari jenis biota perairan. Selain itu, secara ekonomis dapat digunakan sebagai energi seperti kayu bakar, arang, bahan bangunan, sumber potensi perikanan, pertanian, bahan tekstil, bahan penyamak dan produk ekonomi lainnya. Hutan mangrove yang menempati daerah pasang surut dan dipengaruhi oleh arus laut, mengalami perubahan secara terus menerus. Ekosistem hutan mangrove juga tergolong dinamis karena hutan mangrove dapat terus berkembang serta mengalami suksesi sesuai dengan perubahan tempat tumbuh, namun hutan mangrove juga tergolong labil, karena mudah sekali rusak dan sulit untuk pulih kembali (Dahuri, 2003). Pengelolaan mangrove secara berkelanjutan merupakan syarat mutlak yang tidak bisa dihindari untuk menyelamatkan hutan mangrove.

Berbagai fungsi serta manfaat hutan mangrove yaitu fungsi fisik, fungsi biologis dan fungsi ekonomis. Hutan Mangrove secara fisik berfungsi sebagai peredam gelombang dan angin agar tidak merusak daratan, menahan abrasi pantai, mencegah terjadinya intrusi air laut. Fungsi hutan mangrove secara biologis antara lain sebagai tempat berkembangbiak bagi berbagai jenis ikan, kepiting, udang dan jenis hewan lainnya. Secara sosial ekonomis, keberadaan hutan mangrove juga menjadi sangat penting karena bisa menjadi tempat wisata alam, selain itu juga menghasilkan berbagai produk baik kayu dan non kayu yang menjadi daya dukung bagi kehidupan masyarakat yang tinggal disekitarnya Ekosistem hutan mangrove yang rusak akan semakin cepat seiring dengan meningkatnya usaha-usaha perekonomian dan pembangunan di daerah pantai. Perubahan yang terjadi di daerah pesisir pantai dengan mengorbankan kawasan mangrove, sehingga areal mangrove tidak 
berfungsi dengan semestinya. Rusaknya hutan mangrove di Indonesia disebabkan karena meningkatnya konversi lahan sejalan dengan meningkatnya jumlah penduduk. Seiring dengan pertumbuhan penduduk yang semakin cepat, menyebabkan kebutuhan hidup manusia semakin meningkat, sebagai konsekuensinya peningkatan pembangunan dan pemukiman menimbulkan tekanan terhadap pemanfaatan sumberdaya alam, yang pada kenyataannya belum banyak memperhitungkan kerugian yang berdampak ekologis. Demikian juga halnya dengan pembangunan wilayah pantai sekitar kawasan hutan mangrove, dimana pemanfaatan kawasan pantai untuk tambak ikan tidak dilakukan secara bijaksana dan berwawasan lingkungan. Selain itu, kerusakan juga disebabkan pencemaran limbah industri maupun limbah rumah tangga dari pemukiman sekitarnya dan dampaknya sangat besar.

Ekosistem hutan mangrove biasa ditemukan hampir disetiap wilayah provinsi Sulawesi Utara terlebih khusus di kabupaten Minahasa Utara salah satunya di Desa Kampung Ambong yaitu Hutan mangrove di desa Kampung Ambong, Kecamatan Likupang Timur, Kabupaten Minahasa Utara, merupakan kawasan lindung mangrove sebagian lahan mangrove telah terbuka yang sudah tidak bervegetasi. Sekitar Tahun 1984, kawasan hutan lindung mangrove telah dibuka oleh pengusaha untuk dijadikan tambak, namun setelah di rusak dan dibuka lahannya di biarkan. Kerusakan ekosistem hutan mangrove, akan semakin cepat seiring dengan meningkatnya usaha-usaha perekonomian, pembangunan di daerah pantai. Banyak perubahan yang terjadi di daerah pesisir pantai dengan mengorbankan kawasan mangrove, sehingga areal mangrove tidak berfungsi dengan semestinya. Melihat kerusakan yang dilakukan oleh manusia untuk berbagai kepentingan, maka perlu dilakukan pengelolaan mangrove secara lestari. Untuk bisa melakukan pengelolaan mangrove secara lestari diperlukan nilai strategis dari keberadaan hutan mangrove yang akan memberikan manfaat bagi masyarakat sekitar. Pengelolaan hutan mangrove berbasis masyarakat merupakan salah satu strategi pengelolaan yang dapat meningkatkan efisiensi dan keadilan dalam pemanfaatan dan pengelolaan sumber daya alam. Bila masyarakat pesisir memiliki pengetahuan akan pentingnya hutan mangrove untuk generasi sekarang dan generasi mendatang, maka melibatkan masyarakat dalam pengembangan dan pengelolaan ekosistem hutan mangrove berbasis masyarakat akan menumbuhkan kesadaran masyarakat akan arti pentingnya perlindungan terhadap sumber daya alam. Oleh sebab itu di perlukan upaya untuk menumbuhkembangkan peran serta masyarakat dalam mengembalikan fungsi dan manfaat hutan mangrove yang rusak dalam pelaksanaan dan pengawasan.

\section{Rumusan Masalah}

Berdasarkan uraian latar belakang, maka permasalahan penelitian dibatasi dengan rumusan masalah:

1. Bagaimana partisipasi masyarakat dan faktor-faktor yang mempengaruhi partisipasi masyarakat dalam pengelolaan hutan mangrove di Desa Kampung Ambong Kecamatan Likupang Timur Kabupaten Minahasa Utara,

2. Bagaimana pengelolaan hutan mangrove di Desa Kampung Ambong Kecamatan Likupang Timur Kabupaten Minahasa Utara?

\section{Tujuan Penelitian}

Tujuan penelitian ini adalah :

1. Untuk menganalisis faktor-faktor yang mempengaruhi pengelolaan hutan mangrove di Desa Kampung Ambong Kecamatan Likupang Timur Kabupaten Minahasa Utara;

2. Mendeskripsikan pengelolaan hutan mangrove berbasis masyarakat di Desa Kampung Ambong Kecamatan Likupang Timur Kabupaten Minahasa Utara. 


\section{Manfaat Penelitian}

Diharapkan hasil penelitian ini akan bermanfaat pada pengelolaan sumberdaya alam hutan mangrove secara menyeluruh dengan berorientasi bagi kesejahteraan masyarakat dengan menjaga kelestarian fungsi hutan mangrove.

\section{METODOLOGI PENELITIAN}

\section{Tempat dan waktu Penelitian}

Penelitian ini dilaksanakan di desa Kampung Ambong Kecamatan Likupang Timur Kabupaten Minahasa Utara pada bulan Agustus - Oktober 2017.

\section{Penentuan Responden}

Teknik pemilihan sampel yang digunakan pada penelitian ini adalah sampel dipilih secara sengaja (purposive sampling) yakni penduduk laki-laki atau kepala keluarga (KK).

Penentuan jumlah sampel ditetapkan dengan rumus sebagai berikut (Parel et al, 1973 dalam Dirjen RLL, 1998):

$n=\frac{N z^{2} p(1-p)}{\mathrm{N} d^{2}+z^{2}(1-p)}$

Dimana :

$\mathrm{N}=$ jumlah responden yang diambil

$\mathrm{N}=$ jumlah unit populasi

$\mathrm{Z}=$ nilai variable random (dikehendaki signifikan level $95 \%$ maka $\mathrm{z}=1.960$ )

$\mathrm{p}=$ proporsi yang dapat dijangkau adalah $80 \%$ atau 0,8

$\mathrm{d}=$ maksimum eror yang masih diterima $10 \%$ maka $\mathrm{d}=0,1$

Berdasarkan rumus 1 maka jumlah responden yang diambil adalah sebagai berikut, $\mathrm{n}=55$ responden

\section{Analisis Data}

Metode yang digunakan dalam penelitian ini adalah metode kualitatif karena objek penelitian ini merupakan objek sosial. Analisis partisipasi masyarakat terhadap pengelolaan hutan mangrove dilakukan dengan pendekatan kuantitatif dengan menggunakan Skala Likert. Pengukuran meliputi aspek pengetahuan (kognitif) dan sikap (afektif) dalam pengelolaan hutan mangrove yang selama ini telah dilakukan serta mengukur sejauh mana tingkat partisipasi masyarakat dalam pengelolaan hutan mangrove di Desa Kampung Ambong Kecamatan Likupang Timur Kabupaten Minahasa Utara. Berdasarkan pemahaman terhadap konsep tersebut selanjutnya dibuat kuisioner untuk mengukur tingkat partisipasi menggunakan 4 kategori penilaian jawaban kemudian selanjutnya masing-masing jawaban diberi skala 1-4. Klasifikasi tingkat partisipasi digolongkan dalam 4 kategori yaitu sangat tinggi, tinggi, sedang dan rendah.

1. Tingkat partisipasi terhadap pengelolaan hutan mangrove

a. Kategori sangat tinggi dengan nilai 36-39 dimana responden menjawab pertanyaan dengan ikut terlibat dalam kegiatan pengelolaan hutan mangrove. Artinya responden memiliki pemahaman yang luas tentang pelaksanaan kegiatan pengelolaan hutan mangrove dan memiliki rasa tanggung jawab serta terlibat aktif dalam pengelolaan hutan mangrove.

b. Kategori tinggi dengan nilai 32-35 dimana responden menjawab pertanyaan dengan ingin terlibat dalam kegiatan pengelolaan hutan mangrove. Artinya responden memiliki cukup pemahaman tentang pelaksanaan kegiatan pengelolaan hutan mangrove dan ingin terlibat dalam kegiatan pengelolaan hutan mangrove.

c. Kategori sedang dengan nilai 29-31 dimana responden menjawab pertanyaan dengan tidak tahu. Artinya responden tidak memiliki pemahaman tentang pelaksanaan kegiatan pengelolaan hutan mangrove dan tidak ingin terlibat dalam kegiatan pengelolaan hutan mangrove.

d. Kategori rendah dengan nilai $<29$ dimana responden menjawab pertanyaan dengan tidak ingin terlibat dalam kegiatan pengelolaan hutan mangrove. Artinya responden memiliki pemahaman tentang pelaksanaan kegiatan pengelolaan hutan mangrove tetapi tidak ingin terlibat dalam kegiatan pengelolaan hutan mangrove.

Selanjutnya untuk mengukur hubungan antara faktor sosial ekonomi responden dengan tingkat partisipasi dilakukan dengan analisis non parameterik Rank Spearman. Dalam program analisis SPSS masing-masing kategori diberi skala ordinal yaitu nilai 1 untuk kategori 
rendah, nilai 2 untuk kategori sedang, nilai 3 untuk kategori tinggi dan nilai 4 untuk kategori sangat tinggi sebagai dipenden untuk partisipasi masyarakat dalam pelaksanaan prngelolaan hutan mangrove. Selanjutnya variable bebas terdiri dari umur, tingkat pendidikan, pekerjaan, pendapatan, jumlah anggota keluarga, lama bekerja dan keanggotaan dalam organisasi tentang pengelolaan hutan mangrove. Beberapa persamaan untuk analisis data yang digunakan meliputi:

a. Analisis instrument bertujuan untuk mengukur validitas dengan menggunakan persamaan (2) (Siregar, 2010)

$r=\frac{n \sum x y-\left(\sum x y\right)\left(\sum x y\right)}{\sqrt{\left[n\left(\sum x^{2}\right)-\left(\sum x\right) \mid n\left(\sum y^{2}\right)-\left(\sum y\right)^{2}\right.}}$

Dimana:

$\mathrm{n}=$ jumlah responden

$\mathrm{x}=$ skor variable

$\mathrm{y}=$ skor total variable untuk responden $\mathrm{n}$

b. Analisis korelasi sosial ekonomi yang mempengaruhi tingkat partisipasi menggunakan persamaan (3) (Siregar, 2010)

$r s=1-\frac{6 \sum D^{2}}{n\left(n^{2}-1\right)}$

Dimana:

$r^{s}=$ koefisien korelasi Rank Spearman

$\mathrm{D}=$ perbedaan rangking antara variabel $\mathrm{X}$ dan $\mathrm{Y}$

$\mathrm{n}=$ jumlah kasus atau sampel yang diurutkan

Selanjutnya uji dan uji t digunakan untuk menganalisis tingkat signifikansi hubungan faktor sosial ekonomi dengan tingkat partisipasi dengan menggunakan persamaan (4)

$\mathrm{t}=\mathrm{rs} \frac{\sqrt{n-2}}{1-r s^{2}}$

Untuk analisis data dilakukan dengan menggunakan persamaan-persamaan yang dilakukan dengan bantuan Statistical Pakage for Social Scince (SPSS).

Konsepsi faktor sosial ekonomi sebagai

variabel adalah sebagai berikut:

1) Tingkat partisipasi adalah tingkat/intensitas keikutsertaan responden dalam kegiatan pengelolaan hutan mangrove, yang di ukur berdasarkan jumlah frekuensi dari bentuk, jenis/tipe dan tahapan dalam partisipasi

2) Umur adalah usia responden yang dihitung dari tanggal lahir sampai saat penelitian dilakukan dan dinyatakan dalam tahun

3) Pendidikan formal adalah jenjang pendidikan resmi yang pernah diikuti responden
4) Jenis mata pencaharian pokok adalah jenis mata pencaharian utama yang menopang seluruh kehidupan rumah tangga responden sampai saat penelitian dilakukan

5) Jumlah anggota keluarga adalah jumlah seluruh anggota keluarga yang meliputi bapak, ibu, anak dan orang lain yang menjadi tanggungan keluarga dan dinyatakan dalam orang/jiwa

6) Keanggotaan suatu organisasi adalah keikutsertaan responden dalam suatu organisasi sampai saat penelitian dilakukan

7) Pendapatan adalah tingkat pendapatan total yang diperoleh responden, baik dari mata pencaharian utama maupun di luar mata pencaharian utama dalam satu bulan dan dinyatakan dalam Rp/bulan

Partisipasi masyarakat terhadap pengelolaan hutan mangrove dapat terlihat dari ungkapan hasil wawancara dengan responden itu sendiri serta pertanyaan yang diajukan.

Nilai interval untuk penentuan kriteria ditentukan melalui pengurangan nilai skor tertinggi dikurangi nilai skor terendah dibagi jumlah kriteria (Walangitan, 2012)

$\mathrm{I}=\frac{N t-N r}{K}$

Dimana :

$\mathrm{I}=$ Interval Kelas

$\mathrm{Nt}=$ Nilai Skor Maksimum

$\mathrm{Nr}=$ Nilai Skor Minimum

$\mathrm{K}=$ Jumlah Kriteria

\section{Jenis dan Sumber Data}

Data primer diperoleh dari informasi langsung di lapangan, baik melalui pengisian daftar pertanyaan maupun hasil wawancara langsung dengan responden terpilih. Data sekunder berasal dari monografi desa yaitu data tentang keadaan wilayah dan kependudukan serta dari Dinas/Instansi terkait.

\section{HASIL DAN PEMBAHASAN}

\section{Deskripsi Karakteristik Sosial Ekonomi Responden}

Hasil survey karakteristik sosial ekonomi masyarakat sebanyak 55 responden secara rinci disajikan pada lampiran 1. Hasil analisis statistik deskriptif diuraikan sebagai berikut: 


\section{Umur}

Umur responden (UMR) merupakan faktor yang berpengaruh dalam pengambilan keputusan. Umur berkaitan dengan pengalaman yang akan membentuk persepsi dan perilaku seseorang. Berdasarkan data yang disajikan pada lampiran 1, terlihat bahwa umur responden terendah adalah 24 tahun, tertinggi adalah 71 tahun. Deskripsi frekuensi responden menurut umur disajikan pada gambar Tabel 1.

Tabel 1. Keragaan Umur Responden di Lokasi Penelitian

\begin{tabular}{ccc}
\hline Umur (Tahun) & Jumlah & Persentase \\
\hline $20-30$ & 3 & 5.45 \\
$31-40$ & 13 & 23.64 \\
$41-50$ & 26 & 47.27 \\
$51-60$ & 7 & 12.73 \\
$>60$ & 6 & 10.91 \\
\hline Jumlah & 55 & 100 \\
\hline
\end{tabular}

Sumber : Data Primer Tahun 2017

Dari Tabel 1 terlihat bahwa kelas umur tertinggi responden antara 41-50 tahun $(47,27 \%)$ diikuti kelas umur $31-40$ tahun $(23,64 \%)$. Sebagai umur responden tersebut tergolong pada kategori tenaga kerja dewasa, usia 51-60 tahun (12,73\%), sedangkan persentase responden yang tergolong tenaga kerja muda yaitu kelompok umur 21-30 tahun $(5,45 \%)$. Suatu hal yang menarik dari data hasil survey terdapat $10,91 \%$ petani dan nelayan yang sudah tergolong pada usia lanjut, yaitu berumur $>60$ tahun namun masih beraktivitas dengan profesinya. Hal ini menggambarkan bertambahnya umur harapan hidup di wilayah penelitian.

\section{Pendidikan}

Tingkat pendidikan responden berpengaruh pada kemampuan untuk mendapatkan dan menggunakan informasi tentang pengelolaan hutan mangrove. Jumlah responden menurut lamanya menempuh pendidikan formal disajikan pada grafik 1 .

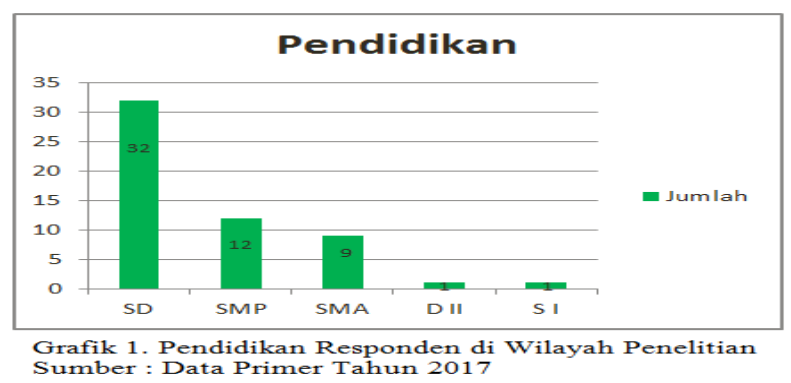

Dari Grafik 1 menunjukkan bahwa sebanyak 32 responden $(58,18 \%)$ menempu pendidikan selama kurang 6 tahun atau berpendidikan sampai tingkat sekolah dasar (SD), 12 responden $(21,82 \%)$ menempuh pendidikan SMP, responden yang menempuh Sekolah Menengah Atas (SMA) sebanyak 9 responden $(16,36 \%)$. Terdapat 1 responden $(1,82 \%)$ untuk lulusan D II dan 1 responden $(1,82 \%)$ lulusan Strata I. Dengan demikian dapat dikatakan bahwa sebagian besar responden memiliki tingkat pendidikan yang tergolong kategori rendah. Pendidikan sangat penting bagi kehidupan masyarakat, karena tingkat pendidikan yang diperoleh responden dapat membantu untuk mendaptkan pekerjaan yang lebih baik dan berpengaruhi pola pikir terhadap segala perubahan yang terjadi di lingkungan sekitar, termasuk dalam kegiatan pengelolaan hutan mangrove. Akan tetapi pada kenyataannya tingkat pendidikan masyarakat khusunya responden masih rendah. Namun demikian status pendidikan bukan faktor tunggal yang berperan dalam pembentukan perilaku responden terhadap pengelolaan hutan mangrove. Pekerjaan atau profesi yang ditekuni oleh responden berpengaruh pada pendapatan untuk kebutuhan hidup responden. Jumlah responden menurut pekerjaan disajikan dalam Tabel 2.

Tabel 2. Pekerjaan Responden di Lokasi Penelitian

\begin{tabular}{lrc}
\hline Pekerjaan & Jumlah & Persentase \\
\hline Nelayan & 33 & 60.00 \\
Petani & 6 & 10.91 \\
Tukang & 6 & 10.91 \\
Swasta & 4 & 7.27 \\
Lainnya & 6 & 10.91 \\
\hline Jumlah & 55 & 100 \\
\hline
\end{tabular}

Sumber : Data Primer Tahun 2017

Dari tabel tersebut sebanyak $60 \%$ responden bekerja sebagai nelayan, diikuti petani $10,91 \%$, tukang 10,91 , swasta $7,27 \%$ dan pekerjaan lainnya seperti Hukum Tua, Pendeta, Imam Masjid dan lainya sebesar 10,91\%.

\section{Jumlah Anggota Keluarga}

Jumlah anggota keluarga yang belum bekerja secara produktif terutama yang masih bersekolah dan orang lanjut usia, walaupun secara sosial masih menggantungkan hidup 
pada orang tua terutama untuk kebutuhan makan, namun jumlah anggota keluarga merupakan gambaran potensi tenaga kerja dalam usaha tani keluarga. Kisaran jumlah tanggungan keluarga responden di lokasi penelitian adalah 1 sampai dengan 6 orang. Dari data karakteristik responden yang terlampir menggambarkan bahwa jumlah anggota keluarga terbanyak 6 orang dan terkecil adalah 1 orang. Responden di lokasi penelitian sebagian besar memiliki jumlah anggota keluarga 4 orang $(36,36 \%)$ sebagai mana disajikan dalam Tabel 3 .

Tabel 3. Jumlah Anggota Keluarga Responden Di Lokasi Penelitian

\begin{tabular}{ccc}
\hline $\begin{array}{c}\text { Anggota Keluarga } \\
\text { (Orang) }\end{array}$ & $\begin{array}{c}\text { Jumlah } \\
\text { Responden }\end{array}$ & Persentase \\
\hline 1 & 3 & 5.45 \\
2 & 7 & 12.73 \\
3 & 15 & 27.27 \\
4 & 20 & 36.36 \\
5 & 8 & 14.55 \\
6 & 2 & 3.64 \\
\hline Jumlah & 55 & 100 \\
\hline
\end{tabular}

Sumber : Data Primer Tahun 2017

\section{Lama Bekerja}

Lama bekerja merupakan masa responden bekerja di suatu bidang usaha tertentu dari masa pertama kali responden bekerja sampai sekarang (periode penelitian). Untuk mengetahui lama bekerjaresponden di lokasi penelitian dapat dilihat pada Tabel 4.

Tabel 4. Lama Bekerja Responden di Lokasi Penelitian

\begin{tabular}{ccc}
\hline $\begin{array}{c}\text { Lama Bekerja } \\
\text { (Tahun) }\end{array}$ & $\begin{array}{c}\text { Jumlah } \\
\text { Responden }\end{array}$ & Persentase \\
\hline $0-10$ & 19 & 34.55 \\
$11-20$ & 26 & 47.27 \\
$21-30$ & 7 & 12.73 \\
$31-40$ & 2 & 3.64 \\
$41-50$ & 1 & 1.82 \\
\hline Jumlah & 55 & 100 \\
\hline Sumber : Data Primer Tahun 2017
\end{tabular}

Tabel 4 menunjukkan bahwa persentase responden dan lama bekerja 11 tahun sampai 20 tahun sebesar 47,27\%, diikuti 0-10 Tahun bekerja $34,55 \%$, lama bekerja 21 tahun sampai 30 tahun sebesar $12,73 \%$, lama bekerja 31 tahun sampai 40 tahunsebesar $3,64 \%$ dan lama bekerja 41 tahun sampai 50 tahun sebesar $1,82 \%$.

\section{Pendapatan}

Tinggi rendahnya pendapatan masyarakat menetukan bagi terciptanya pengelolaan hutan mangrove. Tabel 5. Menunjukkan bahwa responden dengan pendapatan.

Tabel 5. Penghasilan Responden di Lokasi Penelitian

\begin{tabular}{ccc}
\hline Penghasilan & Jumlah & Persentase \\
\hline$<2.000 .000$ & 34 & 61.82 \\
$2.000 .000-<3.000 .000$ & 15 & 27.27 \\
$3.000 .000-<4.000 .000$ & 4 & 7.27 \\
$>4.000 .000$ & 2 & 3.64 \\
\hline Jumlah & 55 & 100 \\
\hline
\end{tabular}

Sumber : Data Primer Tahun 2017

Responden dengan pendapatan kurang dari Rp. 2.000.000 merupakan responden terbesar dengan $61,82 \%$ diikuti dengan pendapatan Rp. 2.000.000 sampai dengan kurang dari Rp. 3.000.000 sebesar 27,27\%, pendapatan Rp. 3.000.000 sampai dengan kurang dari Rp. 4.000.000 sebesar 7,27 \% dan pendapatan di atas Rp. 4.000.000 sebesar $3,64 \%$.

\section{Keanggotaan Dalam Organisasi}

Organisasi adalah kesatuan sosial yang dikoordinasikan secara sadar, yang memungkinkan anggota mencapai tujuan yang tidak dapat dicapai melalui individu secara perorangan. Responden dalam keanggotaan suatu organisasi masyarakat di lokasi penelitian dapat di lihat pada Tabel 6 .

Tabel 6. Penghasilan Responden di Lokasi Penelitian

\begin{tabular}{ccc}
\hline Penghasilan & Jumlah & Persentase \\
\hline$<2.000 .000$ & 34 & 61.82 \\
$2.000 .000-<3.000 .000$ & 15 & 27.27 \\
$3.000 .000-<4.000 .000$ & 4 & 7.27 \\
$>4.000 .000$ & 2 & 3.64 \\
\hline Jumlah & 55 & 100 \\
\hline
\end{tabular}

Sumber : Data Primer Tahun 2017

Tabel 6 menunjukkan responden dengan kategori tidak terlibat dalam organisasi menempati persentase terbesar yaitu 74,55\% dibandingkan dengan responden yang teribat dalam suatua organisasi sebesar $25,45 \%$ yaitu sebagai Anggota kelompok tani hutan, karang taruna dan organisasi lainnya. 


\section{Analisis Partisipasi}

\section{a. Partisipasi Terhadap Hutan dan Fungsinya}

Analisis partisipasi responden terhadap pengelolaan hutan mangrove dilakukan dengan menggunakan metode Skala Likert. Skala Likert digunakan dengan skala 1 (sangat rendah/sangat tidak setuju dengan pertanyaan), 2 (tidak setuju), 3 (setuju) dan 4 (sangat tinggi/sangat setuju dengan pertanyaan). Hasil uji reliabilitas instrumen kuisioner yang digunakan untuk mengukur partisipasi masyarakat terhadap pengelolaan hutan mangrove diperoleh nilai Alpha Cronbach 0,802 yang berarti dapat dipercaya dengan kategori tinggi (lampiran 2). Sedangkan uji validitas kuisioner untuk mengetahui sejauh mana skor atau ukuran yang diperoleh benar-benar menyatakan hasil pengukuran atau pengamatan yang ingin diukur (Siregar, 2010). Hasil uji validitas menunjukkan bahwa semua item pertanyaan yang diajukan untuk mengukur partisipasi masyarakat termasuk kategori valid dengan demikian instrument yang digunakan layak (lampiran 3).

Hasil rekapitulasi nilai partisipasi setiap responden terhadap pengelolaan hutan mangrove selanjutnya dibuat kategori, dimana nilai tertinggi adalah 39 dan nilai terendah 26. Hasil pengurangan antara skor tertinggi dan terendah tersebut dibagi dalam empat kelas dengan rentang nilai masing-masing dengan menggunakan persamaan (5).

Berdasarkan persamaan tersebut diperoleh kategori tingkat partisipasi sebagai berikut: tingkat partisipasi sangat tinggi dengan rentang nilai $36-39$, tingkat partisipasi tinggi rentang nilai $32-35$, tingkat partisipasi sedang dengan rentang nilai 29-31, dan tingkat partisipasi rendah dengan nilai $<29$.

Tabel 7. Persentase Responden Menurut Tingkat Partisipasi Terhadap Pengelolaan Hutan Mangrove

\begin{tabular}{llll}
\hline $\begin{array}{c}\text { Interval } \\
\text { Nilai }\end{array}$ & Kategori & Jumlah & Persentase \\
\hline $36-39$ & Sangat & 6 & 10.91 \\
& Tinggi & & \\
$32-35$ & Tinggi & 11 & 20.00 \\
$29-31$ & Sedang & 26 & 47.27 \\
$<29$ & Rendah & 12 & 21.82 \\
\hline Jumlah & & 55 & 100 \\
\hline
\end{tabular}

Sumber : Data Primer Tahun 2017
Partisipasi adalah hal turut berperan serta pada suatu kegiatan, dengan demikian maka dapat dikatakan bahwa partisipasi memiliki arti yang sama dengan peran serta responden di dalam mengikuti kegiatan pengelolaan hutan mangrove. Sebagai anggota Kelompok Tani Hutan (KTH) tahapan kegiatan pengelolaan hutan mangrove diawali dengan tahapan kegiatan perencanaan yang dilaksanakan lewat pertemuan Kelompok Tani Hutan yang membahas rencana yang akan dilakukan dalam pengelolaan hutan mangrove seperti kegiatan rehabilitasi hutan mangrove. Peran serta masyarakat harus diikuti dengan tindakan dan kesediaan dalam melakukan penanaman mangrove secara sukarela serta bersedia untuk memelihara mangrove.

\section{Pengaruh Faktor Sosial Ekonomi Terhadap Tingkat Partisipasi}

Analisis korelasi Rank Spearman digunakan untuk mengetahui faktor sosial ekonomi responden yang mempengaruhi tingkat partisipasi. Hasil uji korelasi Rank Spearman disajikan pada Tabel 8.

Tabel 8. Hasil Analisis Korelasi Faktor Sosial Ekonomi Dengan Tingkat Partisipasi Responden Terhadap Pengelolaan Hutan Mangrove

\begin{tabular}{|c|c|c|}
\hline Faktor Sosial Ekonomi & $\begin{array}{c}\text { Koefisien } \\
\text { Korelasi }\end{array}$ & Kategori \\
\hline Umur & 0,02 & $\begin{array}{l}\text { Sangat } \\
\text { Lemah }\end{array}$ \\
\hline Pendidikan & 0,26 & Cukup \\
\hline Jumlah Anggota Keluarga & 0,10 & $\begin{array}{l}\text { Sangat } \\
\text { Lemah }\end{array}$ \\
\hline Lama Bekerja & 0,17 & $\begin{array}{l}\text { Sangat } \\
\text { Lemah }\end{array}$ \\
\hline Pendapatan & 0,15 & $\begin{array}{l}\text { Sangat } \\
\text { Lemah }\end{array}$ \\
\hline $\begin{array}{c}\text { Keanggotaan Dalam } \\
\text { Organisasi }\end{array}$ & 0,30 & Cukup \\
\hline
\end{tabular}

Sumber : Data Primer Tahun 2017

Dari data tersebut dapat dilihat bahwa responden tergolong dalam kategori umur produktif dengan kata lain potensi sumber daya manusia cukup tersedia, namun hasil koefisien korelasi Rank Spearman faktor karakteristik umur penduduk tidak memiliki korelasi yang kuat dengan tingkat partisipasi dalam pengelolaan hutan mangrove di Desa Kampung Ambong Kecamatan Likupang Timur Kabupaten Minahasa Utara. Untuk hubungan tingkat pendidikan dengan tingkat 
partisipasi adalah cukup. Pendidikan seseorang merupakan cerminan tingkat penguasaan seseorang terhadap suatu pengetahuan dan aplikasinya terlihat sebagai perilaku hidup di masyarakat . Pendidikan tinggi seseorang belum menggambarkan keikutsertaan dalam pengelolaan hutan mangrove atau tidak berpengaruh dengan tingkat partisipasi responden.

Jumlah anggota keluarga merupakan keanggotaan seseorang dan bergantung pada kepala keluarga. Faktor karakteristik jumlah anggota keluarga responden tetap tidak terlihat karena hubungannya sangat lemah, jadi tidak mempengaruhi tingkat partisipasi responden. Faktor karakteristik lama bekerja, tidak memiliki korelasi yang nyata dengan tingkat partisipasi dalam pengelolaan hutan mangrove. Hubungan pendapatan dengan tingkat partisipasi, tinggi rendahnya pendapatan masyarakat menentukan terciptanya pengelolaan hutan mangrove. Rendahnya pendapat responden tetap mendorong masyarakat menguras sumber daya alam untuk keperluan hidupnya. Hal ini menimbulkan masalah kemiskinan tapi dalam penelitian ini berpendapatan tinggi ataupun rendah tetap tidak memiliki hubungan dengan pengelolaan hutan mangrove karena korelasinya sangat lemah.

Faktor karakteristik keanggotaan suatu organisasi memiliki suatu korelasi positif yang nyata dengan tingkat partisipasi, dimana hubungannya cukup. Semakin tinggi keanggotan dalam suatu organisasi maka akan menjadi semakin tinggi tingkat partisipasi responden atau semakin rendah keanggotaan dalam suatu organisasi, maka tingkat partisipasinya semakin rendah.

\section{Pengelolaan Hutan Mangrove Berbasis Masyarakat di Desa Kampung Ambong Kecamatan Likupanga Timur Kabupaten Minahasa Utara}

Pengelolaan hutan mangrove didasarkan pada isu ekologi, isu ekonomi, kelembagaan dan perangkat hukum serta strategi dan pelaksanaan. Dalam hal ini strategi dan pelaksanaan pengelolaan hutan mangrove memiliki dua konsep utama yang ditetapkan yaitu perlindungan hutan mangrove dan rehabilitasi hutan mangrove. Kedua konsep tersebut pada dasarnya memberikan legitimasi dan pengertian bahwa mangrove sangat memerlukan pengelolaan dan perlindungan agar dapat tetap lestari. Salah satu cara yang dapat dilakukan dalam rangka perlindungann terhadap keberadaan hutan mangrove di Desa Kampung Ambong Kecamatan Likupang Timur Kabupaten Minahasa Utara adalah dengan menetapkan suatu kawasan hutan mangrove untuk dijadikan bentuk sabuk hijau di sepanjang pantai dan tepi sungai. Sedangkan usaha rehabilitasi dilakukan untuk memulihkan kondisi hutan mangrove yang telah rusak agar dapat menjalankan kembali fungsinya dengan baik. Pengelolaan hutan mangrove di Desa Kampung Ambong Kecamatan Likupang Timur Kabupaten Minahasa Utara dilakukan oleh Kelompok Tani Hutan "Tanjung Asa". Kelompok Tani Hutan (KTH) "Tanjung Asa" merupakan kelompok penggerak yang dibentuk pada tanggal 5 Desember 2011. Bentuk pengelolaan yang dilakukan kelompok ini adalah merehabilitasi mangrove di Desa Kampung Ambong Kecamatan Likupang Timur Kabupaten Minahasa Utara. Kegiatan yang pernah dilakukan antara lain:

1) Pada bulan Maret 2012 melakukan kegiatan penanaman mangrove dengan luas $5 \mathrm{Ha}$ dengan jumlah bibit 12.500 , dengan jarak tanam $1 \times 1$ meter.

2) Pada tahun 2013 melakukan penanaman mangrove seluas $10 \mathrm{Ha}$ dengan jumlah bibit 25.000 dengan jarak tanam 1 x 1 meter. Jenis mangrove yang ditanam adalah Rhizopora sp.

Tahun 2013 sampai dengan sekarang melaksanakan kegiatan penanaman dengan cara acak atau tambal sulam. Proses penanaman mangrove biasanya dilakukan pada musim penghujan, karena pengaruh faktor suhu dan kelembaban. Untuk proses penanaman Rhizopora yaitu sebagai berikut: 
1) Langkah pertama yaitu pengadaan bibit yang sudah siap dalam polybag dan siap untuk ditanam serta mempersiapkan pembuatan stick penyangga secukupnya yang terbuat dari kayu atau bambu berukuran panjang $\pm 30 \mathrm{~cm}$ serta tali raffia secukupnya.

2) Langkah kedua membuat kubangan di tanah dengan diameter $15-20 \mathrm{~cm}$ dan dengan kedalaman $\pm 20-30 \mathrm{~cm}$.

3) Langkah ketiga dimasukkannya bibit tanaman mangrove yang sudah siap dalam polybag ke dalam tanah yang sudah disiapkan.

4) Langkah selanjutnya adalah pemasangan penyangga pada sisi-sisi bibit tanaman mangrove dengan stick yang terbuat dari kayu atau bambu, kemudian ujung yang di atas disandarkan pada batang bibit tanaman mangrove dan diikat dengan raffia. Sedangkan ujung yang satunya, yang berada di bawah ditancapkan ke dalam tanah dengan kedalaman secukupnya.

Selain melakukan rehabilitasi, masyarakat Desa Kampung Ambong Kecamatan Likupang Timur Kabupaten Minahasa Utara juga melakukan pemeliharaan dan pengawasan. Pemeliharaan dan pengawasan yang ditujukan terhadap tanaman mangrove berupa observasi terhadap keadaan tanaman di hutan mangrove, guna menjaga apakah tanaman mangrove masih dalam keadaan yang baik atau tidak, terutama tanaman baru dari hasil rehabilitasi yang rentan terhadap gangguan hama. Sedangkan pengawasan yang dilakukan terhadap pengguna hutan mangrove masih sebatas dengan pendekatan emosional, yaitu dengan cara menegur dan memperingatkan kepada pihak-pihak yang seenaknya menebang pohon.
Pengawasan dilakukan oleh seluruh masyarakat Desa Kampung Ambong Kecamatan Likupang Timur Kabupaten Minahasa Utara. Jika masyarakat melihat pelanggaran tersebut, masyarakat dapat langsung melapor kepada salah satu pengurus kelompok dan kemudian pengurus kelompok akan memberikan teguran ataupun penyitaan alat yang digunakan dalam penebangan pohon, atau akan ditindaklanjuti ke kepala desa maupun ke Polisi Kehutanan Kabupaten Minahasa Utara. Masih banyak warga masyarakat yang belum ikut berpartisipasi dalam kegiatan pengelolaan mangrove dikarenakan belum tergabung dalam kelompok tani hutan, begitupun tingkat kepedulian masih sangat rendah. Namun dibalik ketidakpedulian sebagian masyarakat Desa Kampung Ambong, Kelompok Tani Hutan (KTH) Tanjung Asa terus melaksanakan kegiatan rehabilitasi dan terus mengajak warga untuk ikut serta walaupun belum menjadi anggota kelompok tani hutan dengan mengikutsertakan dalam pelatihan-pelatihan tentang manajemen pengelolaan kawasan hutan mangrove, teknik rehabilitasi, perawatan dan perlindungan tanaman mangrove yang dilaksanakan Kementerian Kehutanan melalui Dinas Kehutanan Kabupaten Minahasa Utara.

\section{KESIMPULAN DAN SARAN}

\section{Kesimpulan}

Dari hasil penelitian yang dilakukan dapat disimpulkan:

1. Tingkat partisipasi dalam pengelolaan hutan mangrove berbasis masyarakat di Desa Kampung Ambong Kecamatan Likupang Timur Kabupaten Minahasa Utara hanya faktor tingkat pendidikan dan keanggotaan dalam organisasi yang memiliki korelasi yang cukup. 
2. Pengelolaan hutan mangrove berbasis masyarakat di Desa Kampung Ambong, Kecamatan Likupang Timur, Kabupaten Minahasa Utara dilakukan oleh Kelompok Tani Hutan (KTH) Tanjung Asa seluruh anggota kelompok bersama keluarga giat dalam menanam kembali hutan mangrove dalam kegiatan rehabilitasi hutan mangrove, jenis bibit Rhizophora yang banyak ditanam.

\section{Saran}

1. Untuk meningkatkan partisipasi masyarakat dalam pengelolaan hutan mangrove diperlukan peran pemerintah untuk melaksanakan pendidikan yang bersifat non formal melalui penyuluhan dan pelatihan tidak hanya kelompok tani hutan tetapi melibatkan seluruh masyarakat Desa Kampung Ambong Kecamatan Likupang Timur Kabupaten Minahasa Utara.

2. Perlu dilakukan penelitian lanjutan tentang pengembangan ekowisata mangrove di Desa Kampung Ambong Kecamatan Likupang Timur Kabupaten Minahasa Utara.

\section{DAFTAR PUSTAKA}

Arimbi, Mas Achmad Santosa. 1993. Peran Serta Masyarakat Dalam Pengelolaan Lingkungan. WALHI. Jakarta.

Bengen, D. G. 2000. Teknik Pengambilan contoh dan analisis data biofisik sumberdaya pesisir. Pusat kajian sumberdaya pesisir dan lautan. Fakultas Perikanan dan Ilmu Kelautan Institut Pertanian Bogor. Bogor, Indonesia

Bengen, D. G. 2001. Ekosistem dan sumberdaya pesisir dan laut serta pengelolaan secara terpadu dan berkelanjutan.Prosiding pelatihan pengelolaan wilayah pesisir terpadu. Bogor, 29 Oktober - 3 November 2001.
Dahuri, R. 2003. Keanekaragaman Hayati Laut. Jakarta: PT Gramedia Pustaka Utama.

Kementerian Kehutanan Balai Pengelolaan Hutan Mangrove wilayah 1. 2013. Rancangan areal model pembangunan kebun arboretum mangrove dalam rangka pengembangan hasil hutan bukan kayu (HHBK) mangrove di desa Likupang Kampung ambong Kecamatan likupang timur,Kabupaten Minahasa Utara.

Kinnon J., Kathy Mac Kinnnon. 1990. Pengelolaan Kawasan yang Dilindungi di Daerah Tropika. Gadjah Mada.University Press. Yogyakarta.

Koentjaraningrat. 1980. Kebudayaan Mentalitet dan Pembangunan. PT Gramedia. Jakarta.

Kusmana, C, dkk. (2003). Teknik Rehabilitasi Mangrove. Bogor: Fakultas Kehutanan Institut Pertanian Bogor.

Kusmana, C. 1996. Manajemen Hutan Mangrove di Indonesia..Laboratorium Ekologi Manajemen Hutan Fakultas Kehutanan Institut Pertanian Bogor. Bogor.

Mamuko, F. 2016 Persepsi dan Partisipasi Masyarakat Dalam Upaya Rehabilitasi Hutan dan Lahan di Kabupaten Bolaang Mongondow Timur Provinsi Sulawesi Utara. Manado.

Melana, D.M, Emma, E.Melana,M.F and A,M Mapalo 2000. Mangrove Managemen and development in Philippines. Presented during the meeting on' Mangrove and aquaculture Management@ helt at Kasetsart Univ.Campus, Bangkok, Thailand on February 14-16. 
Mubyarto. 1984. Strategi Pembangunan Pedesaan. Pusat Penelitian Pembangunan Pedesaan dan Kawasan. Universitas Gajah Mada. Yogyakarta.

Nontji, A. 2005. Laut Nusantara. Jakarta: Djambatan.

Nuddin Harahap, Graziano R.2010.Analisis Indikator utama pengelolaan hutan mangrove berbasis masyarakat di desa Curahsawo kecamatan Gending Kabupaten Probolinggo. Jurnal Sosek KP Vol.6 No.1 Tahun 2011

Sastropoetro, S. 1988. Partisipasi, Komunikasi Persuasi dan Disiplin dalam Pembangunan. Alumni Bandung.
Siregar, S. 2010. Statistika Deskriptif untuk Penelitian. PT. RajaGrafindo Persada.

Syukur Djazuli, Aipassa dan Arifin. 2007. Analisis Kebijakan Pelibatan Masyarakat dalam mendukung Pengelolaan Hutan Mangrove di Kota Bontang. Jurnal Hutan dan Masyarakat. Vol. 14. N0. 2 Desember 2007.

Walangitan, H. D. 2012 Analisis Keragaan Sistem Usaha Tani Konservasi Pada Daerah Tangkapan Air Danau Tondano. 